\title{
Sistem sosial budaya masyarakat Indonesia dalam kurikulum pembelajaran Ilmu Pengetahuan Sosial tingkat menengah pertama
}

\author{
Rohani Rohani $^{\left.{ }^{*}\right)}$, Ishak Abdulhak ${ }^{2}$, As'ari Djohar ${ }^{2}$, M. Fahli Zatrahadi ${ }^{1}$ \\ ${ }^{1}$ Universitas Islam Negeri Sultan Syarif Kasim Riau \\ ${ }^{2}$ Universitas Pendidikan Indonesia
}

\section{Article Info \\ Article history: \\ Received Jan $04^{\text {th }}, 2021$ \\ Revised Feb $05^{\text {th }}, 2021$ \\ Accepted Feb 24 ${ }^{\text {th }}, 2021$ \\ Keyword: \\ Socio-cultural system \\ Cultural values \\ Learning curriculum}

\begin{abstract}
Education has a very close relationship to the change of values and culture, therefore in order to achieve the purity of the culture, education needs to form a strong individual person, in order to achieve a golden Indonesia by not softening existing values and cultures. Therefore, it is important to conduct this research aiming to find out the socio-cultural system of the Indonesian people in the social science learning curriculum for the junior secondary level in the province of Riau. This study uses descriptive evaluative design with mixed method type that mixed method. Purposive smpling is a sampling technique used by researchers, with several stages of data collection including: observation, interview, documentation and questionnaires. After research and results were obtained that the 2013 curriculum is better used in junior high school students compared to KTSP, by using the 2013 curriculum and a qualified strategy in the learning process can increase students' curiosity towards learning and social problems in the environment, students can understand the learning well and deeper into the value of Malay culture.
\end{abstract}

\section{Corresponding Author:}

Rohani Rohani

Universitas Islam Negeri Sultan Syarif Kasim Riau

Email: rohani@uin-suska.ac.id

\section{Pendahuluan}

Pendidikan merupakan upaya pengaplikasian ilmu yang dilakukan secara sadar oleh manusia (Suci et al., 2018), pendidikan diselenggarakan bertujuan agar kemurnian sistem nilai budaya dalam segala aspek kehidupan masyarakat tetap terjaga dengan baik (Yuristia, 2018). Dalam pengembangan nilai, pendidikan dan budaya memiliki peran penting serta memiliki hubungan yang saling mempengaruhi (reciprocal relationship) (Suradi, 2018). Pendidikan dikatakan sebagai proses pembudayaan tiga komponen vital yakni tata kehidupan (order), suatu proses (process), serta bervisi tertentu (goals) dimiliki oleh kebudayaan (Mitayani, Suwanli, \& Wijaya, 2016).

Hubungan yang terjadi antar manusia mengakibatkan kondisi masyarakat mengalami perubahan (Poerwati \& Endarwati, 2019), perubahan yang terjadi secara signifikan tersebut mewujudkan globalisasi yang menimbulkan persaingan secara kompetitif antar masing-masing individu maupun kelompok manusia (Hendrastomo, 2007). Eksploitatif sangat rentan terjadi, hal inilah yang harus di hilangkan dalam pola hubungan tersebut (Warung, 2018). Bangsa Indonesia kaya akan sistem nilai dan budaya (Ningsih, 2019), seiring perkembangan zaman dan pertumbuhan globalisasi sistem nilai dan budaya di Indonesia mengalami perubahan (Nahak, 2019; Subiyakto \& Mutiani, 2019), hal ini harus menjadi titik focus kurikulum.

Pengembangan kurikulum perlu di lakukannya untuk mewujudkan Indonesia yang lebih baik (Suluh, 2018), Jika konsep ini di hubungkan dengan peran pendidikan sebagai agen perubahan pada nilai-nilai social budaya (Setiawan \& Sulistiani, 2019), maka sangat penting dijadikan sebagai kurikulum dalam pembelajaran 
terutama pada mata pelajaran IPS (Wahyudi, 2011), karena Ilmu Pengetahuan Sosial merupakan mata pelajaran yang miniaturnya bersumber dari kehidupan social masyarakat (Widiastuti, 2017). Kurikulum IPS harus mampu membangun jati diri bangsa yang sesuai dengan karakteristik bangsa Indonesia dengan memposisikan tatanan nilai yang saling berhubungan antara satu dengan yang lain (Towaf 2014). Dengan adanya pendidikan IPS ini di harapkan dapat membentuk masyarakat yang mendunia (Kholis, 2014) dan tetap berpijak pada kemurnian tatanan nilai sistem budaya yang mampu menyadari dimana ia hidup serta memahami bahwa kehidupan akan terus mengalami perubahan, sehingga akar budaya yang dimiliki tidak hilang dari dalam diri individu maupun masyarakat.

Dalam Naskah Akademik mata pelajaran IPS 2007 bertujuan untuk: "Mengembangkan potensi peserta didik agar peka terhadap masalah sosial yang terjadi di masyarakat, memiliki sikap mental positif terhadap perbaikan segala ketimpangan yang terjadi dan melatih ketrampilan untuk mengatasi setiap masalah yang terjadi sehari-hari baik yang menimpa diri sendiri atau masyarakat" (Departemen Pendidi kan Nasional, 2007).

Sesuai dengan kuadratnya IPS merupakan studi yang berkaitan dengan tingkah laku manusia yang di peroleh dari kehidupan nyata. Oleh karena itu Masalah social masyarakat yang kontemporer seperti rendahnya etos kerja dan menurunnya jiwa kewirausahaan harus mampu teratasi melalui pembelajaran IPS. Berdasarkan tujuan tersebut mata pelajaran IPS harus mampu melahirkan manusia yang dapat memenuhi kebutuhan dan sistem nilai budaya Indonesia. Dengan demikian Konsep mata pelajaran IPS yang meliputi bahan kajian Sosiologi, Sejarah, Geografi dan Ekonomi dan antropologi yang disederhanakan untuk Pendidikan Dasar dan Menengah merupakan adaptasi dari disiplin Ilmu-ilmu Sosial dan humaniora, serta kegiatan dasar manusia yang diorganisir dan disajikan secara ilmiah dan pedagogis/psikologis untuk tujuan pendidikan (Endayani 2017).

Program atau materi dalam pembelajaran merupakan bagian dari kurikulum yang akan di laksanakan (Wekke 2015). Dengan adanya kurikulum IPS ini di harapkan mampu membantu para peserta didik memiliki nilai social yang tinggi dan mampu menjaga ke stabilan gaya hidup sesuai dengan lingkungan tempat tinggalnya. Akan tetapi, Pendidikan yang di kemas dalam bentuk kurikulum saat ini belum mampu memenuhi hasil yang di harapkan (Suyitno, 2012). Pada pendidikan dasar dan menengah pembelajaran ilmu sosial cenderung menggunkan kurikulum yang terpisah (Pujatama, 2014), dimana setiap mata pelajaran merupakan komponen yang berdiri sendiri dalam kurikulum dan memiliki tujuan tertentu dalam kesatuan yang utuh. Pemisahan dalam kurikulum ini mengakibatkan wawasan peserta didik menjadi bersekat antar setiap dimensi ilmu (sosiologi, sejarah, geografi, ekonomi) yang di pelajari hingga tidak ada keterpaduan di dalamnya (Putra, 2020).

Hal ini tentu saja membuat tujuan IPS yang dirumuskan sesuai realitas dan fenomena social untuk mencapai kesatuan yang utuh dari cabang-cabang ilmu sosial itu sendiri tidak tercapai. Untuk mencapai tujuan tersebut kurikulum IPS harus memberikan gambaran mengenai adanya kesatuan yang terintegritas dalam kurikulum. Fenomena lapangan yang di temukan, para peserta didik merasa keberatan untuk menguasai mata pelajaran secara keseluruhan dan menilai bahwa masing-masing mata pelajaran terlalu memberatkan. Model pembelajaran terpadu adalah middle way yang di tawarkan agar dapat di aplikasikan pada peserta didik, mulai dari jenjang Sekolah Dasar sampai dengan Sekolah Menengah Atas (Setyowati \& Fimansyah, 2018). Model pembelajaran terpadu tersebut dapat memberikan pandangan terhadap kehidupan dunia nyata sehingga individu mampu memenuhi kebutuhan dan nilai masyarakat tempat dimana ia tinggal. Oleh karena itu penulis melakakukan penelitian ini dengan tujuan untuk mengetahui sistem sosial budaya masyarakat Indonesia dalam kurikulum pembelajaran IPS tingkat menengah pertama di provinsi Riau.

\section{Metode}

Penelitian ini menggunakan metode evaluasi yang bertujuan mengukur keterlaksanaan pembelajaran IPS berbasis nilai-nilai budaya Melayu dalam membentuk kompetensi sosial peserta didik SMPN di kota Pekanbaru Provinsi Riau. Penelitian ini menggunakan desain deskriptif evaluative (Nugrahani \& Hum, 2014), dimana hanya menjelaskan mengenai fakta-fakta yang terlihat dan di temukan di lapangan tanpa memberikan tambahan dengan perubahan pada masing-masing variable. Penelitian ini di tekankan pada data kuantitaif yang di perkuat dengan data kualitatif, dengan data kualitati data yang di peroleh menjadi lebih jelas dan lebih tajam, oleh karena itu dalam penelitian ini, peneliti menggunakan penelitian jenis mixed method yang memadukan antara dua jenis penelitian, penelitian jenis kualitatif dan jenis kuantitaif yang di kombinasikan menjadi satu penelitian (Hermawan, 2019; Sarwono, 2013). 
Teknik pengumpulan data pada proses perolehan data dalam penelitian ini peneliti menggunakan beberapa teknik pengumpulan, diantaranya adalah, Observasi, Wawancara, Dokumentasi, Angket. Subjek penelitian, stakeholder di berbagai bidang studi IPS di Provinsi Riau, Tokoh agama di Provinsi Riau, Tokoh masyarakat, adat budaya di Provinsi Riau. Populasi dalam penelitian ini adalah Guru Sekolah Menengah Pertama yang berada dalam cakupan wilayah provinsi Riau. Populasi dari penelitian ini adalah sekolah SMPN yang berada dalam wilayah yang sama, terdiri dari 40 orang guru IPS dari SMPN Kota Pekanbaru Provinsi Riau, yang terdiri dari 37 orang guru dari SMPN dengan menggunakan kurikulum 2006 (KTSP), dan 3 orang guru dari SMPN yang menggunakan kurikulum 2013. SMPN 1198 Siswa, SMPN 10317 Siswa, SMPN 29167 SIswa, SMPN 23232 Siswa, SMPN 40174 Siswa. Pengambilan sampel dengan teknik purposive sampling dimana teknik ini memberikan kekuasaan utuh kepada peneliti untuk menentukan wakil (key informant) dari jumlah populasi yang ada. Sampel Penelitian Tenaga Pendidik SMP di Kota Pekanbaru Guru IPS kelas VIII, SMPN1 1 Guru, SMPN10 1Guru, SMPN6 1 Guru, SMPN29 1 Guru, SMPN23 1 Guru, SMPN40 1 Guru.

Sampel penelitian diambil dengan secara acak (purposive sampling) mempertimbangkan hal-hal sebagai berikut: 1) lokasi terjangkau oleh peneliti; 2) antara sekolah yang dipilih berada pada lokasi yang bersamaan di dalam setiap kecamatan; 3) mengingat tahun pelajaran 2015-2016 yang menggunakan Kurikulum 2013 hanya tiga SMPN sebagai pilot project, yaitu SMPN 1, SMPN 6, dan SMPN 23. Oleh karena itu, dipilih juga tiga SMPN yang menggunakan KTSP yakni SMPN 10, SMPN 29, dan SMPN 40, maka akan menjadi seperti ini. Sampel Penelitian Peserta Didik SMP di Kota Pekanbaru, SMPN 198 Siswa, SMPN 6317 Siswa, SMPN 23300 Siswa dengan menggunakan Kurikulum 2013. Sedangkan untuk SMPN yang menggunakan kurikulum 2006 terdapat SMPN 10167 Siswa, SMPN 29232 Siswa, SMPN 40174 Siswa. Sampel penelitian terdiri dari guru-guru bidang studi IPS di SMPN di provinsi Riau sebagaimana dapat dilihat pada tabel 3.3 di atas terdiri atas tiga orang guru di SMPN yang menggunakan kurikulum 2013 dan tiga yang menggunakan KTSP. Sampel peserta didik ditetapkan dengan rumus Solvin, dengan rumusan penetapan sampel adalah $\mathrm{n}$ $=\mathrm{N} / 1+\mathrm{N}(\mathrm{f})^{2}$ sehingga diperoleh sampel peserta didik dari SMPN yang menggunakan kurikulum 2013 berjumlah 204 orang dan yang menggunakan kurikulum 2006 (KTSP), berjumlah 145 orang.

\section{Hasil dan Pembahasan}

Dalam Membentuk Kompetensi sosial peserta didik SMPN yang menggunakan kurikulum 2013 bersifat terpadu bersumber filsafat pendidikan progesivisme dan rekonstruksivisme. Filsafat progesivisme membentuk jiwa demokratis dalam kehidupan sehari-hari di masyarakat. Setiap peserta didik memunyai tanggung jawab dan kesadaran diri untuk Membentuk diri sendiri secara aktif berdasarkan nilai-nilai budaya Melayu karena individu adalah faktor yang dapat menentukan apa yang baik dan benar. Filsafat pendidikan rekonstruktivisme dalam pembelajaran bidang studi IPS pada jenjang SMPN bertujuan memberikan bekal Kompetensi sosial kepada peserta didik agar menjadi manusia yang beradab dan bermartabat di lingkungan masyarakat sehingga dapat berpartisipasi aktif dalam kegiatan-kegiatan pemenuhan kepentingan dan kesejahteraan.

Perencanaan pembelajaran adalah suatu proses pembuatan rencana, model, pola, bentuk. Hasil evaluasi terhadap perencanaan pembelajaran tenaga pendidik bidang studi IPS maka RPP tenaga pendidik SMPN yang menggunakan kurikulum 2013, RPP tenaga pendidik bidang studi IPS SMPN yang menggunakan kurikulum 2013 merupakan suatu proses memahami beragam dokumen normatif dan alternatif (buku teks atau sumber lain) serta realitas kontekstual. Membentuk indikator tenaga pendidik SMPN perlu mempertimbangkan tuntutan kompetensi yang dapat dilihat melalui kata kerja yang digunakan dalam KD dan karakteristik mata pelajaran, peserta didik, dan sekolah serta potensi dan kebutuhan peserta didik, masyarakat, dan lingkungan/daerah. Kegiatan pendahuluan atau pra instructional salah satu upaya agar dapat melibatkan.

Perpartisipasi aktif dalam kegiatan inti pembelajaran secara menyenangkan terpadu dan bermakna melalui pengkodisian mental, pengetahuan, emosi, fisik, media, dan lingkungan belajar peserta didik secara efektif agar dapat mewujudkan kondisi awal pembelajaran yang kondusif. Kegiatan inti pada RPP tenaga pendidik SMPN yang menggunakan KTSP dan kurikulum 2013 mampu memberikan pengalaman dan kemampuan belajar kepada peserta didik secara aktif, bermakna dan terpadu melalui pendekatan saintifik dimana peserta didik mencari tahu sendiri dari berbagai sumber tentang bahan pelajaran yang sedang dipelajari.

Kegiatan menutup pada RPP tenaga pendidik SMPN yang menggunakan kurikulum 2013 belajar mengajar secara bermakna dan berkesinambungan dengan cara meninjau kembali penguasaan inti dan 
mengevaluasi, merangkum materi pembelajaran dalam kaitannya dengan nilai-nilai Budaya Melayu, berupa: memberikan tugas, menyimpulkan materi, refleksi hasil pembelajaran hari itu, dan berdoa. Berdasarkan hasil evaluasi terhadap telaah dokumen RPP bidang studi IPS berbasis nilai-nilai budaya Melayu di SMPN yang menggunakan kurikulum 2013 dan KTSP, telah sesuai dengan ketentuan standar proses kurikulum yang berlaku. Evaluasi pembelajaran yang dilakukan lebih berorientasi pada RPP untuk membentuk kompetensi sosial peserta didik berbasis budaya Melayu. Hal ini dibutikan dari hasil rekapitulasi data yang menunjukkan, bahwa terdapat kategori alternatif "d" berjumlah 18,71 \%. Pada kategori level tiga dengan alternatif "c" bahwa muatan kompetensi sosial dalam RPP pada kategori cukup baik dengan jumlah $63,93 \%$, dan $15,53 \%$ masuk pada alternatif "b" dengan kategori baik, serta hanya 1,83 $\%$ masuk pada alternatif "a" dengan kategori sangat baik.

Terdapat kategori alternatif "e" bahwa, dapat ketahui bahwa Muatan RPP tidak mencantumkan atau memasukkan unsur nilai kompetensi sosial berbasis budaya Melayu berjumlah $0.13 \%$, dan pada kategori level dua dengan alternatif "d" bahwa muatan nilai budaya Melayu berada pada kategori yang redah dengan jumpah $33.94 \%$, Sedangkan untuk kategori cukup baik berjumlah $34.61 \%$, dan $25.08 \%$ masuk pada alternatif " $b$ " dengan kategori baik, serta hanya $1.34 \%$ masuk pada alternatif "a" dengan kategori sangat baik. Merujuk hasil perbandingan data prosentasi RPP berbasis nilai-nilai budaya Melayu bidang studi IPS yang dirancang tenaga pendidik jenjang SMP dari kelompok kurikulum 2013 dan KTSP di SMPN Kota Pekanbaru, menunjukkan bahwa muatan nilai kompetensi sosial berbasis budaya Melayu, yang tidak jauh berbeda dan memiliki kecenderungan yang sama. Sehingga masih perlu dioptimalkan muatan kompetensi sosial dari RPP pembelajaran IPS.

Maknanya keberhasilan pembelajaran bidang studi IPS dalam membentuk kompetensi sosial peserta didik berbasis nilaiu-nilai budaya Melayu bergantung pada kompetensi dan kualitas tenaga pendidik IPS dalam membuat RPP dan pengetahuan tenaga pendidik IPS terhadap nilai-nilai budaya yang sesuai dengan kompetensi sosial peserta didik tersebut. Didasarkan hasil data tentang pengetahuan tenaga pendidik IPS tentang nilai budaya Melayu bervariasi serta cenderung rendah. Hal ini sesuai pernyataan Kepala Sekolah Menengah Pertama (SMP) Negeri 1 Kota Pekanbaru, bahwa:

"Selama ini ketidakpahaman tentang nilai budaya Melayu, disebabkan tidak ada pedoman yang jelas, menjadi sumber rujukan dari semua tenaga pendidik -tenaga pendidik terhadap nilai budaya Melayu, sehingga dalam membuat rancangan pelaksanaan pembelajaran (RPP) dan pelaksanaan pembelajaran, sangat minim nilai-nilai budaya Melayu, kadang tidak mengerti jika kompetensi sosial yang terdapat dalam proses pembelajaran sesuai dengan nilai budaya Melayu." Armiati, Wawancara. 3 Maret 2016).

Implementasi Rencana Pelaksanaan Pembelajaran (RPP) sesuai dengan Permendiknas Nomor 41 Tahun 2007 tentang Standar Proses untuk SMPN yang mempergunakan KTSP dan Permendiknas Nomor 103 Tahun 2014 tentang Standar Proses untuk SMPN yang mempergunakan kurikulum 2013. Implementasi kurikulum dituntut untuk melaksanakan sepenuhnya apa yang telah direncanakan dalam kurikulum itu sendiri untuk dijalankan dengan segenap hati dan keinginan kuat. Rancangan kurikulum dan impelementasi kurikulum adalah sebuah sistem yang membentuk sebuah garis lurus dalam hubungannya (konsep linearitas) dalam arti implementasi mencerminkan rancangan maka sangat penting sekali pemahaman tenaga pendidik serta aktor lapangan lain yang terlibat dalam proses belajar mengajar sebagai inti kurikulum untuk memahami perancangan kurikulum dengan baik dan benar.

Implementasi pembelajaran merupakan hal yang sangat menentukan dalam keberhasilan peserta didik menguasai kompetensi dasar. Dalam merencanakan implementasi pembelajaran perlu dipertimbangkan indikator keberhasilan belajar. Proses pembelajaran pada tenaga pendidikan SMPN yang menggunakan kurikulum 2013 lebih baik dibandingkan tenaga pendidik yang menggunakan KTSP karena telah menjadi kompetensi utama tenaga pendidik dalam memulai kegiatan pembelajaran agar dapat menkondisikan mental dan fisik peserta didik dengan bersih sehingga dapat memberikan dampak positif terhadap pemahamanan dan penerapan materi pelajaran yang akan dipelajari dalam kehidupan sehari-hari.

Kompetensi bertanya tenaga pendidik bidang studi IPS SMPN yang menggunakan kurikulum 2013 merupakan upaya mendorong partisipasi aktif peserta didik dalam kegitan pembelajaran baik dalam bentuk bertanya atau menjawab pertanyaan sehingga dapat meningkatkan proses pembelajaran lebih bermakna dan demokratis. Kompetensi bertanya tenaga pendidik upaya menuntun proses berpikir peserta didik agar dapat memusatkan perhatian terhadap masalah yang sedang dibahas.

Kompetensi bertanya pada tenaga pendidik SMPN yang menggunakan kurikulum 2013 lebih baik dibandingkan tenaga pendidik yang menggunakan KTSP karena dapat membangun sikap ilmiah dan demokratis pe Universitas Islam Negeri Sultan Syarif Kasim Riau serta didik melalui keterlibatan aktif peserta 
didik dalam Membentuk pola pikir dan cara belajar aktif sehingga dapat membangkitkan minat dan rasa ingin tahu peserta didik terhadap sesuatu masalah yang sedang dibicarakan.

Kompetensi menjelaskan merupakan aspek penting bagi tenaga pendidik bidang studi IPS SMPN yang menggunakan kurikulum 2013 karena sebagian besar percakapan pembelajaran didominasi oleh penjelasan bahan secara langsung maupun tidak langsung dengan memerhatikan hal-hal sebagai berikut: 1) keterkaitan dengan tujuan, 2) relevan antara penjelasan dengan materi, 3) kebermaknaan bagi peserta didik untuk masa sekarang dan yang akan datang, 4) dinamis agar tingkat pemahaman peserta didik terhadap materi yang dipelajari bermakna, mendalam, dan luas.

Kompetensi menjelaskan tenaga pendidikan SMPN yang menggunakan kurikulum 2013 lebih baik dibandingkan tenaga pendidik yang menggunakan KTSP karena telah menjadi media komunikasi antara tenaga pendidik dengan peserta didik untuk memberikan pemahaman, meningkatkan kemampuan berpikir, mengungkapkan gagasan, perasaan, pendapat, persetujuan, keinginan, penyampaian informasi tentang materi yang sedang dipelajari sehingga dapat meningkatkan efektivitas penggunaan waktu dan penyajian penjelasan, mengestimasi tingkat pemahaman, membantu memperluas cakrawala pengetahuan peserta didik, serta mengatasi kelangkaan buku sebagai sarana dan sumber belajar.

Kompetensi mengelola kelas tenaga pendidik bidang studi IPS SMPN yang menggunakan kurikulum 2013 telah terpadu dalam Membentuk Kompetensi peserta didik karena adanya keterhubungan antara nilainilai budaya Melayu dengan langkah-langkah pembelajaran dan keterhubungan antara ganjaran dan penggunaan metode pembelajaran dengan nilai-nilai budaya Melayu sehingga terjadi proses internalisasi nilai-nilai budaya Melayu dalam materi pelajaran dan proses pembelajaran untuk membimbing, menghayati, dan mendalami nilai-nilai budaya Melayu sehingga dapat memperkuat Kompetensi sosial peserta didik.

Kompetensi mengelola kelas tenaga pendidikn bidang studi IPS pada jenjang SMPN yang menggubakan kurikulum 2013 adalah upaya tenaga pendidik dalam menciptakan iklim dan budaya kelas demokratis dengan cara-cara atau pendekatan dan model pembelajaran terpadu sehingga Membentuk kemampuan maksimal individual maupun kelompok, membantu mengatasi hambatan dan membantu belajar sesuai dengan tingkat emosional dan intelektualnya dengan penyediaan fasilitas sebaik mungkin. Hal ini sesuai dengan kompetensi menutup pelajaran bertujuan memberikan gambaran menyeluruh tentang apa yang telah dipelajari oleh peserta didik, mengetahui tingkat pencapaian peserta didik dan tingkat keberhasilan tenaga pendidik dalam proses pembelajaran. Kompetensi menutup pelajaran adalah Kompetensi dasar mengajar yang perlu dikuasai dan dilatihkan bagi calon tenaga pendidik agar dapat mencapai tujuan pembelajaran secara efektif, efisien, dan menarik. Kompetensi menutup pelajaran adalah Kompetensi yang berkaitan dengan kegiatan atau usaha yang dilakukan oleh seorang tenaga pendidik dalam mengakhiri suatu pelajaran.

Kompetensi menutup pembelajaran tenaga pendidikn SMPN yang menggunakan kurikulum 2013 lebih baik dibandingkan tenaga pendidik yang menggunakan KTSP karena telah memberikan gambaran menyeluruh tentang apa yang telah dipelajari oleh peserta didik, mengetahui tingkat pencapaian peserta didik dan tingkat keberhasilan tenaga pendidik dalam proses pembelajaran. Proses pembelajaran IPS berbasis nilai-nilai budaya Melayu di SMPN yang menggunakan kurikulum 2013 telah dapat membentuk seluruh potensi peserta didik secara utuh sesuai tujuan pendidikan nasional serta mampu membangun masyarakat beradab dan demokratis pada masa yang akan datang yang bersumber pada nilai-nilai moral positif dalam kehidupan masyarakat. Sekolah adalah agen perubahan sosial dan agen perubahan moral dalam era globalisasi.

Hal ini terjadi karena peran guru yang tepat saat proses pembelajaran yaitu, sebagai dinamisator, motivator, fasilitator, evaluator untuk meningkatkan kualitas proses pembelajaran dan hasil pembelajaran sangat ditentukan oleh kemampuan interaksi tenaga pendidik dengan peserta didik dalam proses tersebut. Peran tenaga pendidik dalam proses pembelajaran lebih dominan sebagai manajemen pelaksanaan pembelajaran sehingga dapat meningkatkan partisipasi aktif peserta didik dalam pembelajaran.

Tenaga pendidik bidang studi IPS pada jenjang SMP yang menggunakan kurikulum 2013 telah melakukan proses pembelajaran bermakna sebagai suatu kegiatan yang terencana secara sistemetis dan analitis sehingga dapat mempengaruhi terjadinya perubahan perilaku bagi peserta didik, sebagai indikator hasil belajar yang terfasilitasi. Hal ini sesuai dengan hasil rekapitulasi data pelaksanaan pembelajaran, pada SMPN yang menggunakan kurikulum 2013 ddan SMPN yang menggukanan KTSP bahwa pelaksanaan pembelajaran IPS dalam membentuk kompetensi Sosial Peserta didik berbasis budaya nilai-nilai budaya Melayu di jenjang SMPN yang menggunakan Kurikulum 2013, masuk dalam kategori alternatif "e" sebanyak $0.043 \%$ dengan makna bahwa kompetensi sosial peserta didik sosial peserta didik berbasis nilai 
budaya Melayu tidak muncul dalam pelaksanaan pembelajaran IPS, dan sebanyak $26.34 \%$ masuk dalam kategori alternatif jawaban "d" yang dapat mengaplikasikan nilai budaya Melayu dalam pembelajaran IPS, dan untuk kategori cukup baik berjumlah 40,93 \%, dan 19,05 \% masuk pada alternatif "b" dengan kategori baik, serta hanya 6,72 \% masuk pada alternatif "a" dengan kategori sangat baik.

Didasarkan data di atas, kegiatan pembelajaran pada jenjang SMP yang menggunakan kurikulum 2013 telah dapat mengembangkan kompetensi sosial peserta didik pada kategori cukup baik disbandingkan dengan proses pembelajaran tenaga pendidik bidang studi IPS pada kelompok SMPN yang menggunakan kurikulum 2006 (KTSP). Hal ini dapat ditunjukan pada data sebagai berikut: pelaksanaan pembelajaran yang ditelaah, terdapat $0.24 \%$ masuk dalam kategori alternatif poin "e" bahwa sangat tidak terkait, dan $34.73 \%$ kategori tidak baik atau dalam kondisi yang rendah dalam mengintegrasikan muatan nilai kompetensi sosial yang berhubungan dengan budaya Melayu ada dalam pelaksanaan pembelajaran IPS, dan untuk alternatif evaluasi "c" masuk dalam kategori tidak baik dengan jumlah dan kemudian terdapat 40.4 $\%$ masuk dalam kategori cukup baik, dan $18.31 \%$ masuk dalam kategori baik, serta hanya $7.45 \%$ yang masuk dalam kategori sangat baik (alternatif evaluasi "a").

Dengan demikian dapat disimpulkan bahwa kegiatan pembelajaran berbasis nilai-nilai budaya Melayu yang dilaksanakan oleh tenaga pendidik IPS pada jenjang SMP yang menggunakan KTSP dalam membentuk kompetensi sosial peserta didik di Kota Pekanbaru masih harus dioptimalkan kerena berpengaruh pada hasil pembelajaran yang akan dicapai oleh peserta didik. Hal ini terjadi karena berbagai factor salah satunya adalah masih rendahnya pengetahuan tenaga pendidik tentang nilai-nilai budaya Melayu karena kurangnya dukungan untuk ketersediaan buku-buku dan peraturan kepala pemerintahan tentang implementasi nilai-nilai budaya Melayu Riau dalam proses pembelajaran di sekolah.

Pengetahuan tenaga pendidik tentang nilai-nilai budaya Melayu dalam proses pembelejaran di provinsi Riau masih bersifat simbolik sebab belum terintergrasi dalam proses pembelajaran di sekolah. Oleh karena itu, Walikota Pekanbaru menetapkan peraturan No 12 Tahun 2013, pasal 33 ayat (5) dinyatakan bahwa:

"Unsur-unsur muatan lokal budaya Melayu Riau dapat diintegrasikan juga dalam mata pelajaran lainnya." Hal ini bermakna bahwa setiap sekolah mulai dari pendidikan dasar sampai dengan pendidikan Tinggi harus memasukkan konsep muatan nilai-nilai budaya Melayu, baik dalam bentuk Muatan Lokal, atau diintegrasikan ke dalam bidang mata pelajaran langsung. "

Adapun bentuk perhatian pemerintah lainnya terhadap implementasi nilai-nilai budaya Melayu adalah disahkannya Peraturan Gubernur No 75 Tahun 2015, bahwa pendidikan di Riau termasuk kota Pekanbaru harus menerapkan Muatan Lokal Budaya Melayu Riau (BMR). Hal ini menjadi faktor pendukung penting keberadaan nilai budaya Melayu bagi pendidikan di Riau. Dan menurut Kepala Bidang (Kabid) Nilai Budaya Disdikbud Riau;

"Mulok kurikulum BMR ini sudah kami susun melalui Peraturan Gubernur (Pergub). Tinggal pemberitahuan saja," dan "melakukan konsolidasi kepada para budayawan, untuk bahan dan materi kurikulumnya. Sehingga dilanjutkan sosialisasi kesemua sekolah." (Helmiwati Kadir, Wawancara, 7 Mei 2015).

Adapun kendala yang dihadapi oleh pemerintah kota Pekanbaru adalah belum didukung dengan Peraturan Gubernur (Pergub) sehingga sejak tahun 2013 - tahun 2016, Mata pelajaran Muatan Lokal ditiadakan. Hal ini sesuai dengan pernyataan pengawas dari dinas pendidikan Kota Pekanbaru bahwa:

"Tidak ada peraturan Gubernur (Pergub) tentang aturan pembelajaran budaya Melayu, pembelajaran dengan nilai budaya melayu tidak memiliki payung hukum. Oleh karena itu, mata pelajaran khusus seperti muatan lokal (Mulok) menjadi hilang, karena tidak dihitung sebagai jam pelajaran tersendiri dalam sertifikasi. Sehingga tidak ada tenaga pendidik -tenaga pendidik yang mau mengajar mata pelajaran tersebut meskipun tetap dianjurkan dipertahankan, akhirnya pembelajaran nilai budaya Melayu diserahkan pada tenaga pendidik kelas untuk mengintegrasikannya dalam proses pembelajaran." (Syarifah Nurlela, Wawancara, 10 September 2016).

Selama ini mata pelajaran mulok selama ini hanya menekankan pada karya dan tradisi, padahal suatu budaya tidak terbatas pada budaya fisik dalam bentuk karya dan tradisi, banyak nilai-nilai budaya tentang tata aturan tentang bagaimana cara hidup yang lebih baik sesuai nilai budaya yang harus digali untuk menjadi identitas jatidiri masyarakat Melayu. Oleh karena itu, menurut ketua harian LAM Riau, bahwa:

"Pembelajaran nilai yang berkesesuaian dengan norma Melayu yang harus dikembangkan, jadi tidak hanya tanggung jawab tenaga pendidik bidang studi muatan lokal (mulok), tetapi menjadi tanggung jawab bersama. Pembelajaran yang berbasis nilai budaya Melayu, perlu diperhatikan karena selama ini, khusus di kurikulum 
sebelumnya nilai-nilai hakiki tidak dimunculkan di dalam muatan lokal (mulok), maupun dalam proses pembelajaran bidang studi lainnya. (Al Azhar, Wawancara, 10 Januari 2016).

Oleh karena itu, proses intergrasi nilai-nilai budaya Melayu dalam prose pembelajaran dan proses pembelajaran di sekolah belum dapat berjalan dengan baik karena belum memperhatikan tradisi, karya budaya yang bersifat etnologis dan nilai budaya sebagai pedoman tata kelakuan masyarakat. Hal ini sesuai dengan pernyataan Ketua harian Lembaga Adat Melayu Riau bahwa:

"Pembelajaran nilai budaya Melayu, meliputi tiga hal penting yang harus diperhatikan, antara lain; 1) kebiasaan berpola atau disebut dengan tradisi; 2) karya budaya seperti syair, gurindam, musik atau karya-karya lain yang bersifat etnologis; 3) nilai budaya sebagai pedoman tata kelakuan masyarakat." (Al Azhar, Wawancara, 10 Januari 2015).

Dengan demikian diperlukan upaya yang bersifat terintegrasi antara dinas pendidikan dan kebudayaan Riau bersama Lembaga Adat Melayu Riau, mulai dari tingkat provinsi sampai pada tingkat kota/kabupaten, serta kecamatan, untuk meningkatkan pengetahuan tenaga pendidik -tenaga pendidik, termasuk tenaga pendidik IPS tentang nilai budaya Melayu, terutama hal-hal yang berkaiatan langsung dengan kompetensi sosial peserta didik . sehingga terwujud visi Riau 2020 at visi Riau 2025.

Kriteria evaluasi hasil pada penelitian ini adalah standar isi kualifikasi kemampuan lulusan yang mencakup sikap, pengetahuan, dan Kompetensi yang digunakan sebagai acuan utama dalam Membentuk kompetensi sosial peserta didik, meliputi aspek pengetahuan, Kompetensi dan sikap secara terpadu. Hasil belajar aspek pengetahuan meliputi pengetahuan faktual, konseptual prosedural dan meta kognitif berdasarkan bersumber pada standar isi yang berisi kompetensi dasar yang tertuang dalam Permendiknas nomor 24 tahun 2006 untuk SMPN yang menggunakan KTSP dan Permendikbud nomor 64 tahun 2013 untuk kurikulum 2013. Standar isi pada KTSP meliputi aspek pengetahuan dan kurikulum 2013 meliputi aspek pengetahuan, sikap dan Kompetensi . Standar isi adalah ruang lingkup materi dan tingkat kompetensi yang dituangkan dalam persyaratan kompetensi tamatan yang harus dipenuhi peserta didik pada jenjang dan pendidikan tertentu.

Hasil belajar aspek sikap di provinsi Riau telah sesuai dengan Perda Nomor 12 Tahun 2013 tentang Penyelenggaraan Pendidikan Muatan Lokal Budaya Melayu Riau Pasal 33 bahwa: 1) satuan pendidikan formal dan nonformal wajib mengajarkan Mata Pelajaran Muatan Lokal Budaya Melayu Riau; 2) kurikulum muatan lokal budaya Melayu Riau disusun dan ditetapkan oleh pemerintah daerah; 3) buku ajar dan buku pengayaan mata pelajaran Muatan Lokal Budaya Melayu Riau yang digunakan di sekolah wajib memperoleh pengesahan dari pemerintah daerah bekerja sama dengan Lembaga Adat Melayu Riau; 4) pembelajaran muatan lokal budaya Melayu Riau diarahkan pada pengembangan karakter peserta didik; dan 5) unsur-unsur muatan lokal budaya Melayu Riau dapat diintegrasikan juga dalam mata pelajaran IPS.

Hasil pembelajaran IPS di sekolah diharapkan mampu membangun sikap yang sesuai dengan nilai-nilai budaya Melayu sebagai sebuah kompetensi social di masyarakat Provinsi Riau. Sikap dikembangkan pada peserta didik sebagai hasil pembelajaran IPS berbasis nilai-nilai budaya Melayu dari zaman ke zaman sebagai sistem kemasyarakatan agar kompetensi sosial peserta didik sesuai dengan identitas masyarakat Melayu. Adapun bentuk hasil belajar aspek pengetahuan pada peserta didik SMPN di kota Pekanbaru provinsi Riau meliputi: pengetahuan faktual, konseptual prosedural dan meta kognitif berdasarkan bersumber pada standar isi yang berisi kompetensi dasar yang tertuang dalam Permendikbud nomor 64 tahun 2013 untuk kurikulum 2013. Hasil belajar aspek keterampilan atau taksonomi pada domain psikomotor ini kurang menjadi perhatian khususnya di SMPN yang menggunakan KTSP karena belum menjadi alat kelulusan atau kenaikan kelas di sekolah. Sedangkan hasil belajar aspek Kompetensi di SMPN yang menggunakan kurikulum 2013 telah menjadi alat kelulusan atau kenaikan kelas di sekolah sehingga memiliki peran dominan dalam proses pembelajaran di sekolah.

Dukungan sarana prasarana fisik yang dilaksanakan di SMPN yang menggunakan kurikulum 2013 dan KTSP merupakan upaya sekolah dalam memahami dan mendalami Pembelajaran IPS berbasis nilai-nilai budaya Melayu dalam Membentuk Kompetensi Sosial Peserta Didik di sekolah sehingga terbentuk pribadi manusia seutuhnya meliputi aspek pengetahuan, sikap dan Kompetensi . Hasil evaluasi terhadap faktor pendukung berupa sarana prasarana non fisik berupa kegiatan rutin, kegiatan terprogram, kegiatan spontan dan kegiatan keteladanan yang dilaksanakan di SMPN yang menggunakan kurikulum 2013 dan KTSP merupakan merupakan upaya menghayati dan mendalami nilai-nilai-nilai budaya Melayu dalam kegiatan pembelajaran IPS di sekolah sehingga dapat memperkuat Kompetensi social peserta didik. 


\section{Simpulan}

Individu dapat menentukan sesuatu yang baik dan benar oleh karena itu masing-masing individu memiliki beban dan kesadaran diri untuk mengembangkan secara progresif potensi yang dimiliki sesuai dengan nilai-nilai budaya melayu. Dari hasil penelitian dapat disimpulkan bahwa kurikulum 2013 lebih efektif digunakan jika di bandingkan menggunakan KTSP pada sekolah menengah pertama, karena sikap ilmiah serta demokratis yang ada pada diri peserta didik dapat terbangun dan membentuk pola pikir serta mengobarkan rasa ingin tahu peserta didik terhadap sesuatu. Untuk memperkuat kompetensi social peserta didik Sekolah Menengah Pertama dapat menggunakan beberapa strategi yang bisa mendorong siswa agar lebih menghayati dan mendalami nilai budaya melayu dengan sarana prasarana non fisik berupa kegiatan rutin, kegiatan terprogram, kegiatan spontan dan kegiatan keteladanan.

\section{Referensi}

Departemen Pendidikan Nasional. (2007). Naskah Akademik Kajian Kebijakan Kurikulum Mata Pelajaran Ilmu Pengetahuan Sosial (IPS). Jakarta: Badan Penelitian Dan Pengembangan Pusat Kurikulum.

Endayani, Henni. 2017. "Pengembangan Materi Ajar Ilmu Pengetahuan Sosial." IJTIMAIYAH Jurnal Ilmu Sosial Dan Budaya 1(1).

Hendrastomo, G. (2007). Nasionalisme vs Globalisasi 'Hilangnya' Semangat Kebangsaan dalam Peradaban Modern Oleh : Grendi Hendrastomo 1. Jurnal Kajian Sosiologi, I(1), 1-11.

Hermawan, I. (2019). Metodologi Penelitian Pendidikan (Kualitatif, Kuantitatif dan Mixed Method). Jakarta: Hidayatul Quran.

Kholis, N. (2014). Paradigma Pendidikan Islam Dalam Undang-undang Sisdiknas 2003. Jurnal Kependidikan, 2(1), 71-85.

Mitayani, N. A., Suwanli, R., \& Wijaya, M. I. (2016). Model Sekolah Berbasis Budaya di SMP Negeri 3 Banguntapan Bantul. Pelita-Jurnal Penelitian Mahasiswa UNY, 11(2).

Nahak, H. M. . (2019). Upaya Melestarikan Budaya Indonesia Di Era Globalisasi. Jurnal Sosiologi Nusantara, 5(1), 65-76. https://doi.org/10.33369/jsn.5.1.65-76

Ningsih, T. (2019). Tradisi Saparan Dalam Budaya Masyarakat Jawa Di Lumajang Tutuk. Kajian Islam Dan BUdaya, 17, no 1, 79-93. https://doi.org/10.24090/IBDA.V17i1.1740

Nugrahani, F., \& Hum, M. (2014). Metode penelitian kualitatif. Solo: Cakra Books.

Poerwati, T., \& Endarwati, M. C. (2019). Perubahan Sosial Budaya dalam Proses Interaksi Aktivitas Masyarakat di Kecamatan Kuta Kabupaten Badung. Prosiding SEMSINA, 7-14.

Pujatama, P. (2014). Implementasi Kurikulum 2013 pada Mata Pelajaran IPS di Sekolah Menengah Pertama (Studi pada Sekolah-Sekolah di Kota Semarang). Journal of Educational Social Studies, 3(2).

Putra, A. T. A. (2020). Konsep Pemikiran Ismail Raji Al Faruqi (Dari Tauhid Menuju Integrasi Ilmu Pengetahuan di Lembaga Pendidikan). Zawiyah: Jurnal Pemikiran Islam, 6(1), 20-37.

Sarwono, J. (2013). Mixed Methods Cara Menggabung Riset Kuantitatif dan Riset (I). Kuningan: Elex Media Komputindo.

Setiawan, A., \& Sulistiani, I. R. (2019). Pendidikan Nilai, Budaya Dan Karakter Dalam Pembelajaran Matematika Dasar Pada Sd/Mi. Elementeris: Jurnal Ilmiah Pendidikan Dasar Islam, 1(1), 41. https://doi.org/10.33474/elementeris.v1i1.2767

Setyowati, R., \& Fimansyah, W. (2018). Upaya Peningkatan Citra Pembelajaran IPS Bermakna di Indonesia. Jurnal Pendidikan Ilmu Pengetahuan Sosial Indonesia, 3(1), 14-17.

Subiyakto, B., \& Mutiani, M. (2019). Internalisasi Nilai Pendidikan Melalui Aktivitas Masyarakat Sebagai Sumber Belajar Ilmu Pengetahuan Sosial. Khazanah: Jurnal Studi Islam Dan Humaniora, 17(1), 137. https://doi.org/10.18592/khazanah.v17i1.2885

Suci, D. L., Ahzan, S., \& Pangga, D. (2018). Pengembangan Lembar Kerja Siswa (LKS) Fisika Berbasis Gambar Materi Getaran dan Gelombang. Jurnal Penelitian Dan Pengkajian Ilmu Pendidikan: E-Saintika, 1(2), 94. https://doi.org/10.36312/e-saintika.v1i2.108

Suluh, M. (2018). Artikel Penelitian / Article Reviu Perspektif Pendidikan Nasional. Jurnal Penelitian Dan Pengkajian Ilmu Pendidikan: E-Saintika, 2(1), 1-9.

Suradi, A. (2018). Pendidikan Berbasis Multikultural dalam Pelestarian Kebudayaan Lokal Nusantara di Era Globalisasi. Wahana Akademika: Jurnal Studi Islam Dan Sosial, 5(1), 111-130.

Suyitno, I. (2012). Pengembangan Pendidikan Karakter Dan Budaya Bangsa Berwawasan Kearifan Lokal. 
Jurnal Pendidikan Karakter, O(1), 1-13. https://doi.org/10.21831/jpk.v0i1.1307

Towaf, Siti Malikhah. 2014. "Pendidikan Karakter Pada Matapelajaran Ilmu Pengetahuan Sosial." Jurnal Ilmu Pendidikan 20(1).

Wahyudi, D. (2011). Pembelajaran IPS Berbasis Kecerdasan Intrapersonal Interpersonal dan Eksistensial. 1, 33-45.

Warung, Y. E. (2018). Online Shop: Ruang Sosialisasi Diri dan Eksploitasi Konsumtif Masyarakat Milenial. PROLITERA: Jurnal Penelitian Pendidikan, Bahasa, Sastra, Dan Budaya, 1(1), 71-76.

Wekke, Ismail Suardi. 2015. "Tradisi Pesantren Dalam Konstruksi Kurikulum Bahasa Arab Di Lembaga Pendidikan Minoritas Muslim Papua Barat." KARSA: Journal of Social and Islamic Culture 22(1):20-38.

Widiastuti, E. H. (2017). Pemanfaatan Lingkungan Sebagai Sumber Pembelajaran Mata Pelajaran Ips. Satya Widya, 33(1), 29. https://doi.org/10.24246/j.sw.2017.v33.i1.p29-36

Yuristia, A. (2018). Pendidikan Sebagai Transformasi Kebudayaan. Jurnal Ilmu Sosial Dan Budaya, 2(1) 